\title{
Assessment of Public-Private-Participation of Solid Waste Management: A Case Study Warri, Nigeria
}

\author{
Igiekhume M. J. ${ }^{\circledR}$ \\ Momoh E.O. ${ }^{2}$ \\ Jubril A. Al-Amin ${ }^{3}$ \\ Okpugwo E. ${ }^{4}$ \\ Erayanmen R.I ${ }^{5}$ \\ Thomas B. ${ }^{6}$
}

${ }^{1,2,5}$ Department of Urban and Regional Planning, Auchi Polytechnic, Auchi, Nigeria. ${ }^{2}$ Email:mgiekhume@yahoo.com Tel: +2s4(o)7063806735

'Email:emmanuelonuchemomoh@gmail.com Tel: +234(0)8068749450

${ }^{s}$ Department of Electrical \& Electronic Engineering, Auchi Polytechnic, Auchi, Nigeria.

Department of Surveying \& Geoinformatics, Auchi Polytechnic, Auchi, Nigeria.

${ }^{\circ}$ Department of Civil Engineering, Auchi Polytechnic, Auchi, Nigeria.

${ }^{6}$ Email:bosedethomas01@gmail.com Tel: +2348066274339

\begin{abstract}
The menace of indiscriminately disposed heaps of refuse in most urban centers in Nigeria is a confirmation of the inability of the government to cope with the ills associated with rapid population growth rate and urbanization. This study assessed the participation of the private sector in the management and recycling of solid wastes as they together with the public sector strive to attain healthy and neat cities. The Actor Network Theory (ANT) was used as a framework to illustrate the interrelationship, interdependence and co-existence of the different participants in the management of solid waste. This co-existence was revealed to generate several challenges especially for the major Actors such as that of the preference of informal private waste collectors to the registered contractors assigned by the government to their residential areas and the hindrances posed by community youth on Private Sector Participant (PSP). However, from the study it was revealed that the introduction of Private Sector Participant was not enough to check the problems associated with solid waste management. Rather, a holistic approach where all actors, whether householders, formal or informal waste collector, scrap collectors, NGOs or CBOs should be considered by the Government in the policy formulation and implementation in sustainable solid waste management practices.
\end{abstract}

Keywords: Solid waste, Management, Recycling, Participation, PSP, ANT, Policy.

Citation | Igiekhume M. J.; Momoh E.O.; Jubril A. Al-Amin; Okpugwo E.; Erayanmen R.I; Thomas B. (2021). Assessment of Public-Private-Participation of Solid Waste Management: A Case Study Warri, Nigeria. Asian Review of Environmental and Earth Sciences, 8(1): 1-9.

History:

Received: 12 January 2021

Revised: 8 February 2021

Accepted: 25 February 202

Published: 10 March 2021

Licensed: This work is licensed under a Creative Commons

Attribution 3.0 License (cc))

Publisher: Asian Online Journal Publishing Group
Acknowledgement: All authors contributed to the conception and design of the study

Funding: This study received no specific financial support.

Competing Interests: The authors declare that they have no conflict of interests.

Transparency: The authors confirm that the manuscript is an honest, accurate, and transparent account of the study was reported; that no vital features of the study have been omitted; and that any discrepancies from the features of the study have been omitted
study as planned have been explained.

study as planned have been explained.
Ethical: This study follows all ethical practices during writing.

\section{Contents}

1. Introduction

2. Materials and Methods

3. Results and Discussion

4. Conclusion

References 


\section{Contribution of this paper to the literature}

This study assessed the participation of the private sector in the management and recycling of solid wastes as they together with the public sector strive to attain healthy and neat cities.

\section{Introduction}

Wastes are inevitable products of productive and domestic activities. They are unwanted or unusable materials, substances, by-products or left over that have been discarded for lack of use or less importance. Waste in general terms can be liquid or solid in nature and can be hazardous to man and his environment if not well managed. Onu, et al. [1] describe Solid Waste Management as an application of techniques that ensures the orderly execution and disposal of solid waste.

Globally, Solid Waste Management has become an issue because the rate of generation of solid waste far outweighs its management. This can be attributed partly to high population which was projected by United Nations to reach over eight billion by 2030 [2]. The world is undergoing the largest wave of urban growth in history with more than half of the world's population living in towns and cities. This number has been projected to be about 5 billion by 2030 with most of these cities unfolding in Africa and Asia [3]. Urbanization directly contributes to waste generation; as urbanization increases, solid waste generation also increases. The global solid waste generation by urban residents has been estimated to have risen from 680 million tons per year to more than 1.3 million per year, and is expected to rise to 2.2 billion tons by 2025 [4]. In addition, the lack of interest of individuals, organizations and the government in the issue of Waste Management has resulted in its adverse effects on the physical and social environment of man.In general terms, Waste as an issue should not be treated independently from some other urbanization problems like slum, overcrowding, traffic congestion, pollution etc. since any form of solution to them is directed towards creating an aesthetically healthy environment.

In developing countries, the problems associated with waste management demand a radical approach to addressing them. Until recently, in most these countries, Waste management had been the responsibility of the government financed by revenue. In Africa for example, the public sector took monopoly of providing solid waste management in urban centers, and this has largely been blamed for the mess in the management of waste evident in most countries of the continent. The public sector was reported to be constrained owing to lack of managerial and technical capacity, cumbersome procurement procedures and inadequate financial resources [5]. According to Opara [6] the outcome is the indiscriminate refuse dump featured in most African towns and cities. The fact that successive governments in Nigeria have had to contend at one time or the other with the problem of huge mountains of refuse disposed in conspicuous locations in some cities is a clear indication that an appropriate solution is yet to be proffered Odewumi [7]. Filani and Abunere [8] stated that there had been a long frustrating search for an appropriate method of waste disposal. Hence, Akiyode and Sojinu [9] added that, the government began to review the approach of Private Sector Participation (PSP) for better service delivery in Waste Management.

\section{Materials and Methods}

\subsection{Study Area}

Warri metropolis, Warri South Local Government Area is located in Delta State, Delta South Senatorial District, South-South Nigeria, with co-ordinates $5^{0} 31^{\mathrm{I}} \mathrm{N}$ and $5^{0} 45^{\mathrm{I}} \mathrm{E}$ and occupies an area of about $633 \mathrm{~km}^{2}$. Its topography is flat and can be described as a lowland region characterized by natural vegetation of rainforest, with swampy forest and water bodies in some areas. With its tropical equatorial climate, the mean annual temperature is $32.8^{\circ} \mathrm{C}$ and annual rainfall of about $2673.8 \mathrm{~mm}$; it is marked with two distinct seasons: the rainy and dry seasons.

Warri is situated on the coastal part of the delta region of Nigeria and as a result has rich alluvium deposits in its soil and therefore is endowed with crude oil on and off-shore. The growth of the city can be traced to the $15^{\text {th }}$ century when the Portuguese arrived Nigeria, it also served as the colonial capital of the then Warri province, under the colony and protectorate of Southern Nigeria [10].

In the $19^{\text {th }}$ Century, Warri was center for trade of palm oil, rubber, palm products, cocoa, groundnut, hides and skin (http:www.greatestcities.com/Africa/Nigeria/WarriCity_html.) owing to its port activities along the coast of the Warri river. The exploration crude oil in the area in later part of the $20^{\text {th }}$ century made it one of the hubs of petroleum activities and business in southern Nigeria and has a population of over 311,970 people according to 2006 National census. It shares boundary with Ughelli North, Sapele, Okpe, Udu and Uvwie Local Government Areas, most of which have been integrated to the large cosmopolitan Warri. Figure 1 shows map of Nigeria indicating Delta State.

\subsection{Research Design}

The methodology of this study therefore, is patterned to provide answers to the several research questions that pondered the researcher. To do this end, data of various forms were collected from the selected population in the study area by means of well-structured questionnaire, and some brought to the fore through field observation and face to face interviews. However, these data would be presented and analyzed using simple descriptive statistical tools as well as the Chi-Square (X2) to test the stated hypothesis, so that an inference can be drawn from some information gathered. The conclusion reached from the study would help the researcher assess the participation of private and public sector in solid waste management in Warri Metropolis with a view to evolving policy response capable of enhancing waste management efficiency in the area. 

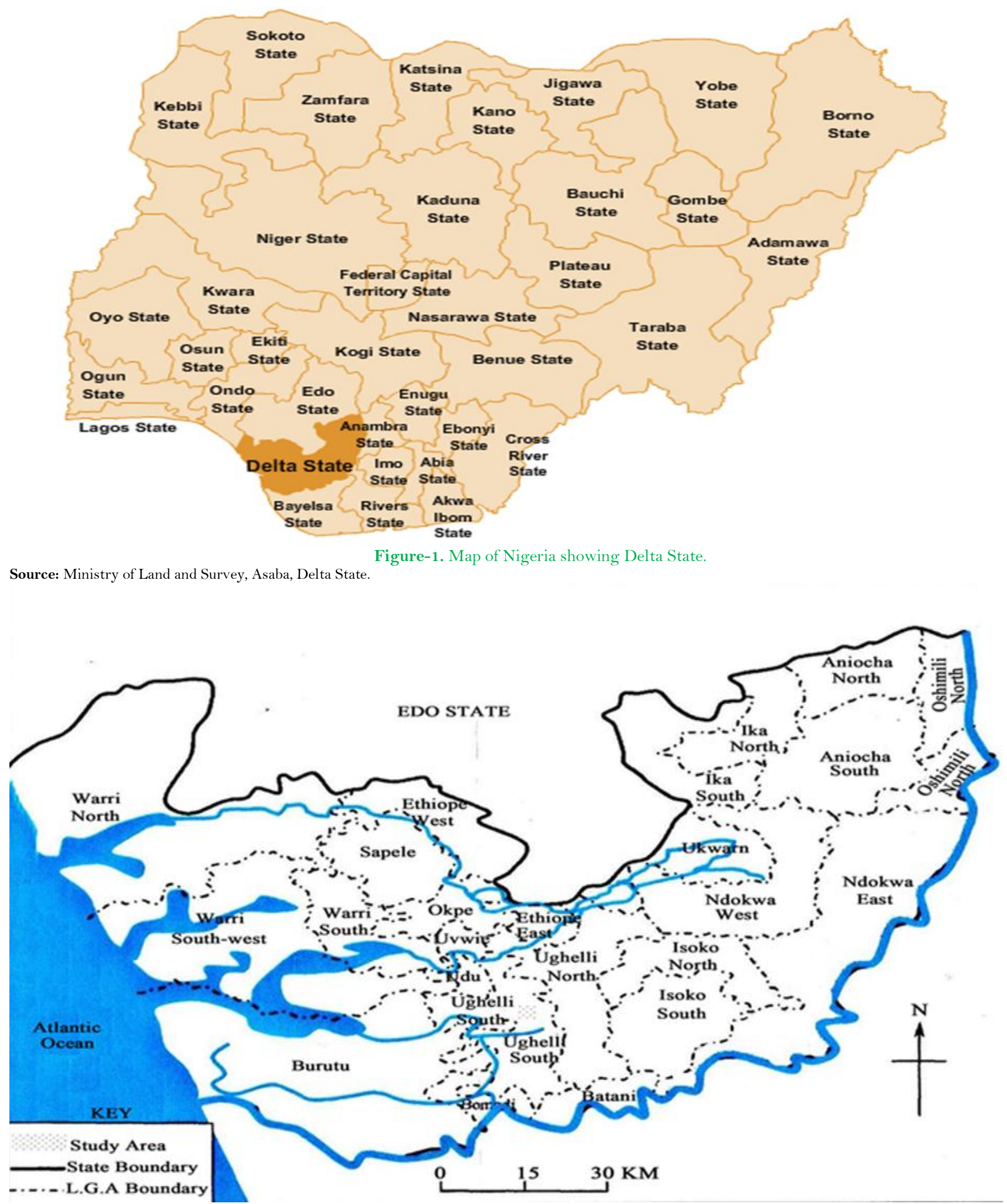

Figure-2. Map of Delta State showing Warri South L.G.A.

Source: Ministry of Land and Survey, Asaba, Delta State.

\subsection{Population of Study}

The Population of this study is a sample of the total population of Warri South Local Government Area. Applying the population growth rate of $2.5 \%$ of Nigeria according World Population prospectus, 2015, and the 2006 National Census, where the population of Warri was recorded as 311,970, this research deemed it necessary to project the population of the area to be 409,332 as at the time of the study from Equation 1:

$$
\mathrm{P}_{1=} \mathrm{P}_{\mathrm{O}}(1+\mathrm{r})^{\mathrm{n}}
$$

Where: $\mathrm{P}_{1=}$ Projected population (Year 2017).

$\mathrm{P}_{0}=$ Population of base year (i.e. 311,970 according to 2006 National Census).

$\mathrm{r}=$ Population growth rate $(2.5 \%$ for Nigeria according to United Nations Department of Economic and Social Affairs Population Division [2]

$\mathrm{n}=$ Time interval between $\mathrm{P}_{1}$ and $\mathrm{P}_{0}\left(\mathrm{P}_{1}-\mathrm{P}_{0}(11\right.$ years $)$.

It is in the light of the above that the study area would be divided into zones within which data would be collected from sample population for the study.

\subsection{Method of Data collection}

2.4.1. Types of Instrument for Data Collection

The following were the instruments used for collecting data:

Questionnaire. 
Face to face interview.

Participant's observation.

\section{Questionnaire:}

This was used to retrieve social-economic data. The questions consisted of open and closed type. The respondents were thus given some degree of liberty self-expression through open responses.

Face to face interview: Oral interviews were conducted with some respondents, some staff of the Department of environment, Warri South Local Government Council, Warri, some the registered solid waste collectors' company as well as some informal participants in the solid waste management industry.

Participants' observation: During the study, the researcher worked in the midst of the inhabitants and therefore from their surroundings, was able to collect data by observation.

\subsubsection{Method of Administering Data Collection Instruments}

At the time of this research, the study area had 10 Political units (Wards) as shown below. However, using the Multistage Sampling Technique, the area was delineated into strata which represented the different Ward within which the questionnaires were equally distributed and randomly administered by the researcher. On the whole, Two hundred questionnaire were administered with twenty (20) within each Ward and from these, data was drawn.

Ward 1 - Essi Area.

Ward 2 - Pessu Area.

Ward 3-Ogunu Area.

Ward 4-Okumagba Area.

Ward 5 - Bowen Area.

Ward 6 - Ekurede Area.

Ward 7 - Okere Area.

Ward 8 - Iyara Area.

Ward 9 - Ugbuwangwe Area.

Ward 10 - Mac Demott Area.

\subsection{Method of Data Presentation and Analysis}

For the purpose of clarity, data were properly checked and coded for completeness and accuracy. The responses were grouped before coding and thereafter, both descriptive and inferential statistics were used in data presentation.

\subsubsection{Descriptive Method of Data Presentation}

For ease of understanding, descriptive Statistics used include simple percentages, bar graphs and pie charts.

\subsubsection{Inferential Method of Data Analysis}

Having used Multistage sampling technique to draw data from the population, Chi-Square $\left(\mathrm{X}^{2}\right)$, a nonparametric inferential statistical tool which is a non-directional (two-tailed test) is used to test the set hypothesis, because it can only indicate relationship but not with direction. Equation 2 is applied to determine the Chi-Square values:

$$
\mathrm{X}^{2}=\sum_{E}^{(O-E) 2}
$$

\subsubsection{Hypotheses Testing Technique}

The statistical technique used to test the hypothesis is Chi- Square $\left(\mathrm{X}^{2}\right)$ since it is a non-parametric statistical tool used for nominal or ordinal data as is the case of this study. However, the T-test is used to test the level of significance the relationship of the selected samples from the population in relation to the hypothesis.

\section{Results and Discussion}

From the study, it was revealed that there were unsightly heaps of refuse in some areas of Warri metropolis; some of these unsightly public refuse dumps were seen in some drains, canals, vacant plots, uncompleted buildings, street corners and pavements. These refuse dumps have contributed to the reduction the aesthetic quality of some areas in the urban center of Warri. The study therefore shows that the introduction of Private Sector Participation in solid waste management has not totally checked the problem of irregular waste disposal in the area. This is because the challenges faced by both the public and private sectors in the management of solid waste are enormous. With regard to environmental sustainability, the actors involved in the management of solid waste in Warri were not actively involved in any form activity that could help to reduce the quantity or quality of household waste disposed into the environment such as that prescribed by the 3R's of Solid Waste Management, Re-duce, Re-use and Re-cycler or the Zero Waste Theory. However, all Actors whether the Government, Private Formal, Private informal or the Householders were only interested in disposing the solid waste generated and generating some revenue from it. The resultant effect is that, Self Disposal and Private Informal (wheelbarrow waste collectors) methods which do not have approved dumpsite therefore contribute to environmental degradation through indiscriminate refuse disposal and the consequent depletion of the ecosystem over time. The Government and the registered contractors (Private Formal) are not left out of this atrocity because they only collect and dispose refuse at one approved site or another with the former not having any concrete policy in place to manage private and government dump sites, refuse being constantly burnt or left to cause flooding in adjoining residential areas. 


\subsection{Sample Population}

On the whole, 200 questionnaires were administered but 182 respondents were able to adequately provide sufficient information needed for the study. The data retrieved, presented and analyzed was therefore based on 182 respondents.

\subsection{Socio- Economic Characteristics of the Respondents}

Of the total respondents, $42 \%$ were males and $58 \%$ were females with $60 \%$ of the total respondents married. Also over $60 \%$ of them were above 30 years of age with all of them being literate, Primary School Living Certificate (PSLC) being the least qualification and 57\% graduates from higher institutions (Tables 1, 2, 3 and 4). These shows that the sample population was mature and therefore provided required the information for the study.

\begin{tabular}{c|c|c}
\multicolumn{3}{c}{ Table-1. Sex of respondents. } \\
\hline Sex & No. & \% \\
\hline Male & 76 & 42 \\
\hline Female & 106 & 58 \\
\hline Total & 182 & 100 \\
\hline
\end{tabular}

\begin{tabular}{l|c|c}
\multicolumn{3}{c}{ Table-2. Marital status } \\
\hline Status & No. & \% \\
\hline Single & 66 & 36 \\
\hline Married & 109 & 60 \\
\hline Seperated & 3 & 2 \\
\hline Widowed & 2 & 1 \\
\hline Divorced & 2 & 1 \\
\hline Total & 182 & 100 \\
\hline
\end{tabular}

Table-3. Age of respondence.

\begin{tabular}{l|c|c}
\hline \multicolumn{3}{|c}{ Table-3. Age of respondence. } \\
\hline Age & No. & \% \\
\hline $15-19$ Years & 9 & 5 \\
\hline $20-24$ Years & 25 & 14 \\
\hline $25-29$ Years & 25 & 14 \\
\hline $30-34$ Years & 22 & 12 \\
\hline $35-39$ Years & 27 & 15 \\
\hline $40-44$ Years & 13 & 7 \\
\hline $45-49$ Years & 2 & 1 \\
\hline $50-54$ Years & 32 & 17 \\
\hline 55 Years And Above & 27 & 15 \\
\hline Total & 182 & 100 \\
\hline
\end{tabular}

Table-4. Educational qualification.

\begin{tabular}{l|c|c}
\hline Qualification & No. & $\%$ \\
\hline P.S.L.C & 9 & 5 \\
\hline J.S.C.E & 12 & 7 \\
\hline S.S.C.E & 33 & 18 \\
\hline O.N.D./N.C.E & 12 & 6 \\
\hline H.N.D/B.S.C & 104 & 57 \\
\hline No Formal Education & 5 & 3 \\
\hline Others & 7 & 4 \\
\hline Total & 182 & 100 \\
\hline
\end{tabular}

In terms of their occupation, $41 \%$ of them were into business, $28 \%$ were Public Servants but holistically, $83 \%$ of them were gainfully employed. While $59 \%$ lived in one or two room apartments, $53 \%$ resided in flats and only $6 \%$ and $3 \%$ lived in duplex and bungalows respectively. Also, $28 \%$ of the sample population had 6 and above persons per households and 24\% lived in apartments with above 6 families per building. See Tables 5, 6, 7 and 8 . This suggests that the respondents largely belong to low and middle income groups and that their economic and domestic activities highly contribute to daily generation of solid waste disposed properly or indiscriminately within the study area.

\begin{tabular}{l|c|c}
\multicolumn{3}{c}{ Table-5. Occupation of respondents. } \\
\hline Occupation & No. & \% \\
\hline Schooling & 27 & 15 \\
\hline Public/Civil Servants & 78 & 41 \\
\hline Business & 51 & 28 \\
\hline Artisan & 3 & 2 \\
\hline Retired & 3 & 2 \\
\hline Private Employee & 12 & 7 \\
\hline Unemployee & 3 & 3 \\
\hline Others & 5 & 100 \\
\hline Total & 182 &
\end{tabular}




\begin{tabular}{l|c|c}
\multicolumn{3}{c}{ Table-6. Types of accommodation. } \\
\hline Type & No. & \% \\
\hline One Or Two Rooms & 25 & 32 \\
\hline Flats & 97 & 53 \\
\hline Duplex & 11 & 6 \\
\hline Semi-Detached & - & - \\
\hline Bungalow & 5 & 3 \\
\hline Others & 10 & 6 \\
\hline Total & 182 & 100 \\
\hline
\end{tabular}

\begin{tabular}{|c|c|c|}
\hline No. Of Families & No. & $\%$ \\
\hline 1 & 24 & 13 \\
\hline 2 & 22 & 12 \\
\hline 3 & 31 & 17 \\
\hline 4 & 35 & 19 \\
\hline 5 & 24 & 13 \\
\hline 6 & 4 & 2 \\
\hline Above 6 & 44 & 24 \\
\hline Total & 182 & 100 \\
\hline
\end{tabular}

\begin{tabular}{l|c|c}
\multicolumn{3}{c}{ Table-8. No of persons per household. } \\
\hline No. Of Persons & No & $\%$ \\
\hline 1 & 12 & 7 \\
\hline 2 & 17 & 9 \\
\hline 3 & 25 & 14 \\
\hline 4 & 41 & 23 \\
\hline 5 & 34 & 19 \\
\hline 6 & 30 & 16 \\
\hline Above 6 & 23 & 12 \\
\hline Total & 182 & 100 \\
\hline
\end{tabular}

\begin{tabular}{l|c|c}
\multicolumn{3}{c}{ Table-9. method of solid waste disposal } \\
\hline Methods & No. & \% \\
\hline Registered Waste Collectors & 42 & 23.1 \\
\hline Local Government Collectors & 15 & 8.2 \\
\hline Wheelbarrow Collectors & 73 & 40.1 \\
\hline Self-Disposal & 52 & 28.6 \\
\hline Total & 182 & 100 \\
\hline
\end{tabular}

From the Table 9 and the chart above, $23.1 \%$ of the total respondents' patronized Registered Waste Collectors, Local Government Waste collectors served only $15 \%$ of them, as much as $40.1 \%$ patronized Wheelbarrow collectors while $28.6 \%$ resorted to self- disposal. This study revealed that the choices of the patronage of Solid Waste Collectors by the residents are linked to the satisfaction derived by them from the services rendered and their charges. A total of $49 \%$ of the respondents were very satisfied and satisfied with their method of refuse disposal while only $12 \%$ were not satisfied at all. From some of their responses, some of the respondents complained that some refuse collectors were not regular and that some of their charges were too high. Table 10 shows the effectiveness in the participation of refuse collectors whether public, private formal or informal.

Table-10. Effectiveness in participation of waste disposal agents.

\begin{tabular}{l|c|c|c|c|c|c|c|c|c|c}
\hline & \multicolumn{2}{|c|}{$\begin{array}{c}\text { Regular } \\
\text { /Effective }\end{array}$} & \multicolumn{2}{c|}{$\begin{array}{c}\text { Irregular/ } \\
\text { Adequate }\end{array}$} & \multicolumn{2}{c|}{$\begin{array}{c}\text { Irregular/ } \\
\text { Poor }\end{array}$} & \multicolumn{2}{l|}{} & \multicolumn{2}{l}{} \\
\hline Agent & No. & $\mathbf{\%}$ & No. & \% & No. & \% & No & \% & Total & \%Total \\
\hline Registered Private & 25 & 13.7 & 11 & 6.1 & 6 & 3.3 & - & - & 42 & 23.1 \\
\hline Local Govt. & 5 & 2.74 & 5 & 2.74 & 5 & 2.74 & - & - & 15 & 8.2 \\
\hline Wheel Barrow & 48 & 26.4 & 7 & 3.8 & 18 & 9.9 & - & - & 73 & 40.1 \\
\hline Self-Disposal & - & - & - & - & - & - & 52 & 28.6 & 52 & 28.6 \\
\hline Total & 78 & 42.84 & 23 & 12.64 & 29 & 15.94 & 52 & 28.6 & 182 & 100 \\
\hline
\end{tabular}

Table-11. Unsightly heaps of refuse.

\begin{tabular}{l|c|c}
\hline Unsightly Refuse Dump In Neighborhood & No. & \% \\
\hline Yes & 75 & 41 \\
\hline No & 107 & 59 \\
\hline Total & 182 & 100 \\
\hline
\end{tabular}

Table-12. Refuse dump close to residence.

\begin{tabular}{l|c|c}
\hline Proximity to House & No. & \% \\
\hline Very Close & 18 & 10 \\
\hline Close & 25 & 14 \\
\hline Not Too Close & 32 & 17 \\
\hline None & 107 & 59 \\
\hline Total & 182 & 100 \\
\hline
\end{tabular}




\subsection{Indiscriminate Disposal of Refuse}

It was revealed from the study that $41 \%$ of the total respondents agreed to occasionally have unsightly heaps of refuse in their environment (see Table 11). Also, from Table 12, 24\% admitted to have indiscriminately disposed refuse very close and close to their residents, and $17 \%$ not too close to their houses. Some of these unsightly public refuse dumps were seen in some locations in the study area such as drains, canals, vacant plots, uncompleted buildings, street corners and pavements. See Figures 13, 14, 15 and 16. All these refuse dumps which have reduced the aesthetic quality of some areas in the urban center, Warri can be attributed to the findings of the survey that as much as $28.6 \%$ of disposed per time. As prescribed by the 3 R's of Solid Waste Management, Re-duce, Re-use and Re-cycle, only $8 \%$ and $5 \%$ re-use and sell respectively. Some sell the sorted items to Chart Pushers, Scrap collectors or buyers Figures 13 and 14 the activities of scavengers and waste pickers who collect recyclable items from refuse dump were also actively involved in Solid Waste management in the study area. On the other hand $2 \%$ destroy the sorted out waste, mostly to prevent re-use of the materials for re-production of fake products and $37 \%$ later dispose them.

\section{Conclusion}

This research has dealt exhaustively with the participation of public and private sector in solid waste management in Warri Metropolis and in the process reviewed literatures, generated and analyzed data in relation to the study, identified challenges faced by both sectors in the management of solid waste and finally initiated policy suggestions that could help to reduce the problem of indiscriminate disposal of refuse in Nigerian Cities thereby making our human environment a healthy and neat place to live.

\section{References}

[1] B. Onu, T. Price, S. Surendran, and S. Ebie, "Solid waste management: A critique of Nigeria's waste management policy," International Journal of Knowledge, Culture and Change Management, vol. 11, pp. 373-399, 2012.

[2] United Nations Department of Economic and Social Affairs Population Division, "World population prospects: The 2015 revision, key findings and advance tables," Working Paper No. ESA/P/WP.2412015.

[3] United Nations Population Fund (UNFPA), For people, planet and prosperity: Delivering a world where every pregnancy is wanted every childbirth is safe and every young person's potential is fulfilled. New York: UNFPA, 2015.

[4] W. Bank, "The world bank annual report. Retrieved from: https://doi.org/10.1596/978-0-8213-8376-6," 2010.

[5] E. O. Longe, "People's perception on household solid waste management in Ojo Local Government Area in Nigeria," Iran, Iranian Journal of Environmental Health Science and Engineering, vol. 6, pp. 209-216, 2009.

[6] J. A. Opara, "Urban waste management in port harcourt metropols of the Niger Delta Region in Nigeria. Retrieved from: http://www.businessschool.infor/...site../updated _version_of_UCN.org. [Accessed 20 November 2017]," 2009.

[7] S. Odewumi, "Appraisal of storage and collection strategies of municipal solid waste in Lagos State," IOSR Journal of Humanities and Social Science, vol. 10, pp. 61-67, 2013.

[8] M. O. Filani and S. Abunere, "Foreasting solid waste management for Nigeria Cities in Adeniji E.O. and I. B Bello-Iman (Eds)," ed, 1986, pp. $193-208$

[9] O. O. Akiyode and O. S. S. Sojinu, "Assessment of private sector participation (PSP) in solid waste management practices in Nigeria (Case Study of Lagos State, Nigeria)," presented at the Journal of Solid Waste Management \& Technology. 21st International Conference on Solid Waste Technology and Management, Philadelphia, PA USA March 26 -29, 2006, 2006.

[10] P. P. Ekeh, Warri City: And British colonial rule in Western Niger Delta. Lagos, Nigeira: Urhobo Historical Society, 2005.

Table-13. The uses of household waste after sorting.

\begin{tabular}{l|c|c}
\hline & NO. & $\mathbf{\%}$ \\
\hline Re-Use & 14 & 8 \\
\hline Sell & 10 & 5 \\
\hline Distroy(E.G By Burning, Shredding) & 3 & 2 \\
\hline Dispose The Later & 67 & 37 \\
\hline Do Not Really Sort Waste & 88 & 48 \\
\hline Total & 182 & 100 \\
\hline
\end{tabular}

Table-14. hypothesis 1 (method of waste disposal and effectiveness in participation of waste disposal agents)

\begin{tabular}{|c|c|c|c|c|c|c|c|c|}
\hline \multirow[b]{2}{*}{ Agent } & \multicolumn{2}{|c|}{$\begin{array}{l}\text { Regular/ } \\
\text { Effective }\end{array}$} & \multicolumn{2}{|c|}{$\begin{array}{l}\text { Irregular/ } \\
\text { Adequate }\end{array}$} & \multicolumn{2}{|c|}{$\begin{array}{c}\text { Irregular/ } \\
\text { Poor }\end{array}$} & \multirow[b]{2}{*}{ Total } & \multirow[b]{2}{*}{ \%Total } \\
\hline & No. & $\%$ & No. & $\%$ & No. & $\%$ & & \\
\hline Registered Private & 25 & 13.7 & 11 & 6.1 & 6 & 3.3 & 42 & 23.1 \\
\hline Local Govt. & 5 & 2.74 & 5 & 2.74 & 5 & 2.74 & 15 & 8.2 \\
\hline Wheel Barrow & 48 & 26.4 & 7 & 3.8 & 18 & 9.9 & 73 & 40.1 \\
\hline Total & 78 & 42.84 & 23 & 12.64 & 29 & 15.94 & 130 & 100 \\
\hline
\end{tabular}

Table-15. Hypothesis 1(Obsrevered/Expected Frquencies)

\begin{tabular}{l|c|c|c|c}
\hline & $\begin{array}{c}\text { Regular/ } \\
\text { Effective }\end{array}$ & $\begin{array}{c}\text { Irregular/ } \\
\text { Adequate }\end{array}$ & $\begin{array}{c}\text { Irregular/ } \\
\text { Poor }\end{array}$ & Total \\
\hline Agent & No. & No. & No. & \\
\hline Registered Private & 25 & 11 & 6 & 42 \\
& $(25.2)$ & $(7.43)$ & $5.37)$ & 15 \\
\hline Local Govt. & 5 & 5 & $(3.35)$ & 73 \\
\hline Wheel Barrow & $(9)$ & 7 & $(18.82)$ & \\
\hline Total & $(48.8)$ & $(12.92)$ & 29 & 130 \\
\hline
\end{tabular}




\begin{tabular}{|c|c|c|c|c|c|}
\hline Cell No. & $\begin{array}{c}\text { Observed } \\
\text { Frequencies }(\mathrm{O}) \\
\end{array}$ & $\begin{array}{c}\text { Expected } \\
\text { Frequencies (E) }\end{array}$ & $(\mathrm{O}-\mathrm{E})$ & $(\mathrm{O}-\mathrm{E})^{2}$ & $(\mathrm{O}-\mathrm{E})^{2} \mathrm{E}$ \\
\hline 1 & 25 & 25.2 & -0.2 & 0.04 & 0.0016 \\
\hline 2 & 11 & 7.43 & 3.57 & 12.74 & 1.72 \\
\hline 3 & 6 & 9.37 & -3.37 & 11.36 & 1.21 \\
\hline 4 & 5 & 9 & -4 & 16 & 1.78 \\
\hline 5 & 5 & 2.65 & 2.35 & 5.52 & 2.08 \\
\hline 6 & 5 & 3.35 & 1.65 & 2.72 & 1.03 \\
\hline 7 & 48 & 43.8 & 4.2 & 17.64 & 0.04 \\
\hline 8 & 7 & 12.92 & -5.92 & 35.05 & 2.71 \\
\hline 9 & 18 & 16.28 & 1.72 & 2.96 & 0.18 \\
\hline TOTAL & & & & $\mathrm{X}^{2}=\sum^{(Q-E) 2}$ & 11.112 \\
\hline
\end{tabular}

\begin{tabular}{l|c|c|c|c|c|c|c|c|c|c}
\multicolumn{8}{c|}{ Table-17. hypothesis 2 (method of Solid waste management and indiscrimate disposal of soild waste). } \\
\hline & $\begin{array}{c}\text { Registered } \\
\text { Private }\end{array}$ & \multicolumn{2}{|c|}{ Local Govt. } & \multicolumn{2}{c|}{$\begin{array}{c}\text { Wheel } \\
\text { Barrow }\end{array}$} & $\begin{array}{c}\text { Self- } \\
\text { Disposal }\end{array}$ & & \\
\hline $\begin{array}{l}\text { Unsighly Heaps of Refuse } \\
\text { Close to Residence }\end{array}$ & No. & $\%$ & No. & $\%$ & No & $\%$ & No & \% & Total & \% Total \\
\hline Yes & 34 & 18.7 & 10 & 5.5 & 65 & 35.71 & 44 & 24.1 & 153 & 84.1 \\
\hline No & 8 & 4.4 & 5 & 2.75 & 8 & 4.4 & 8 & 4.4 & 29 & 15.9 \\
\hline Total & 42 & 23.1 & 15 & 8.2 & 73 & 40.1 & 52 & 28.6 & 182 & 100 \\
\hline
\end{tabular}

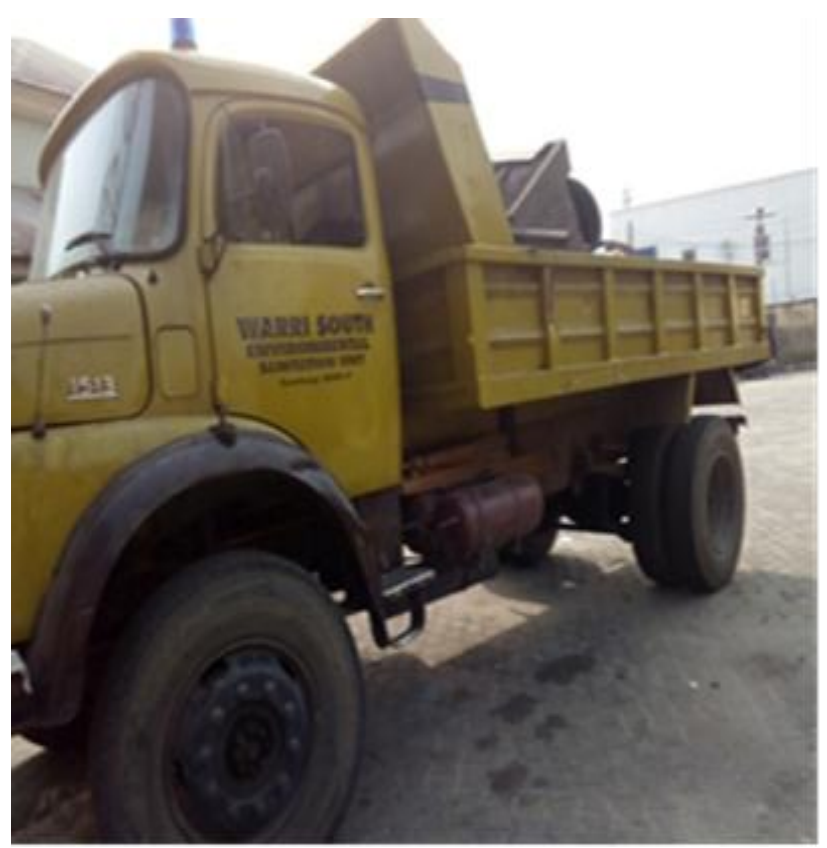

Figure-3. Govt. Waste Tipping Truck 1

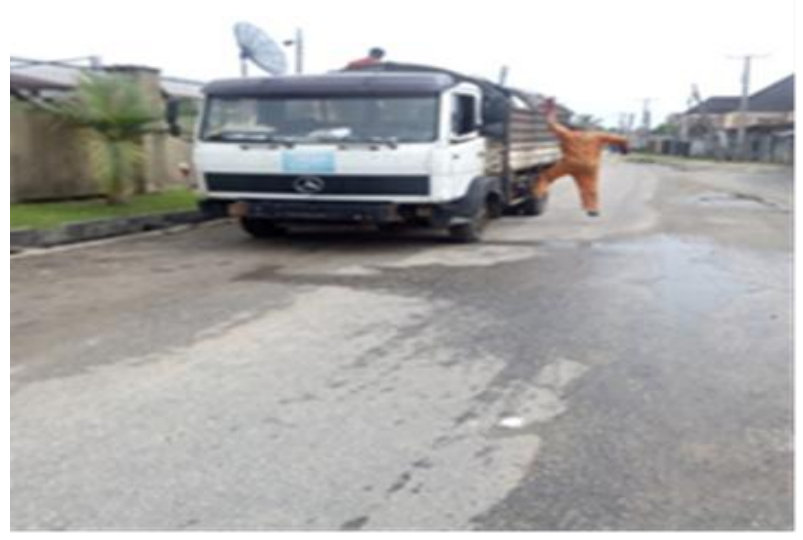

Figure-5. Registered Waste Collector Truck.

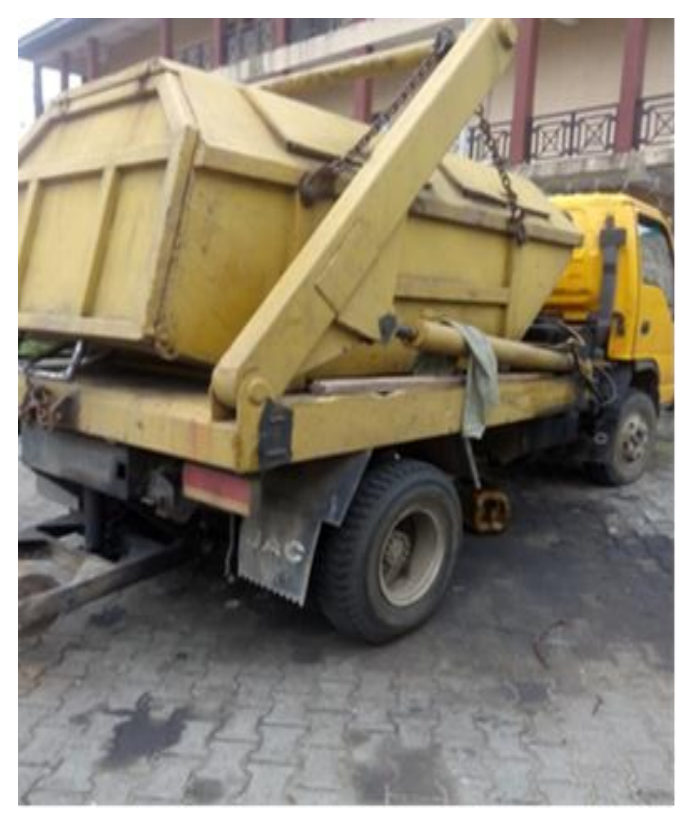

Figure-4. Govt. Waste Collector Truck 2.

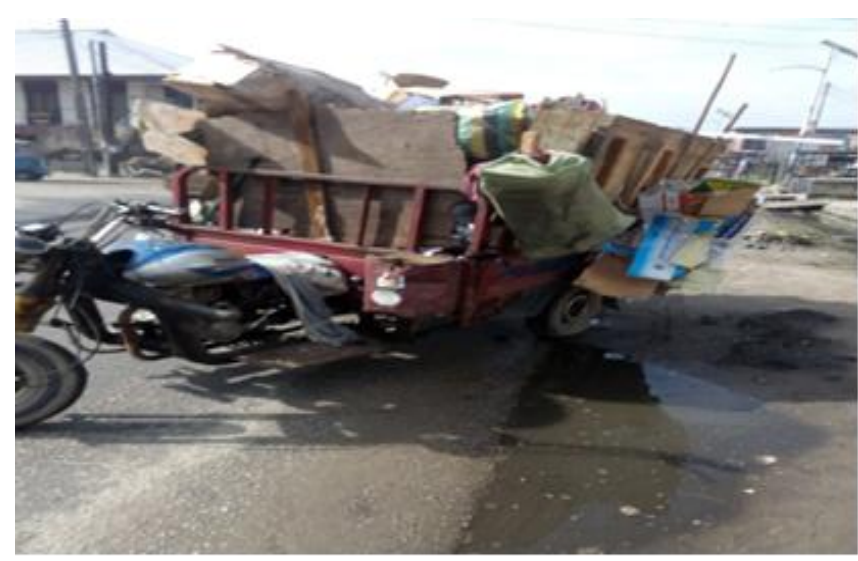

Figure-6. Informal Waste Collector Tricycle. 


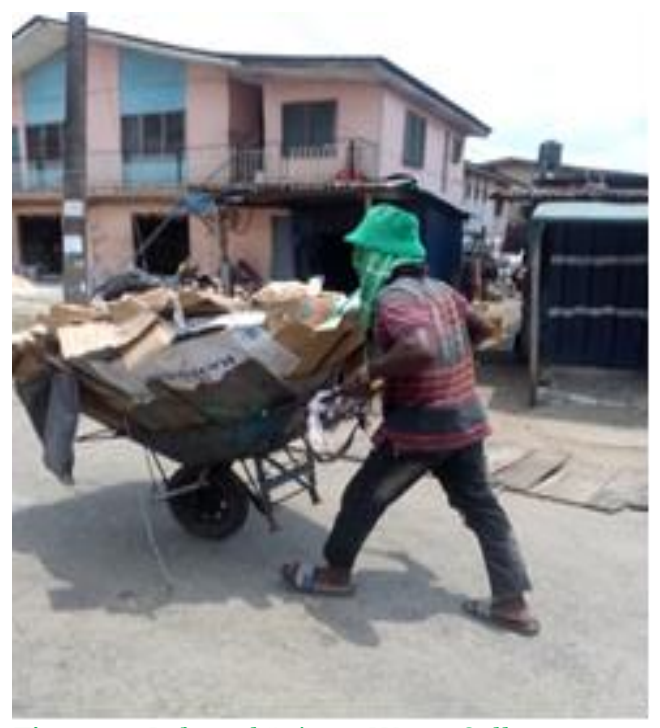

Figure-7. Informal Private Waste Collector.

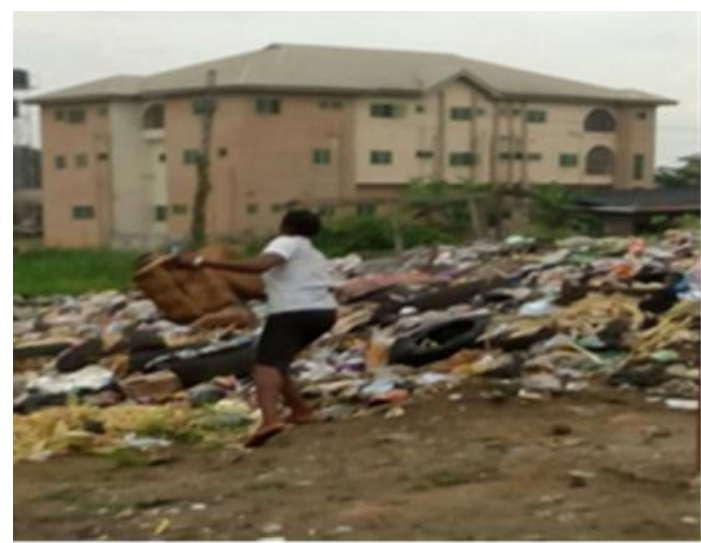

Figure-9. Self-Disposal on a vacant plot, Plaza at Deco Road.

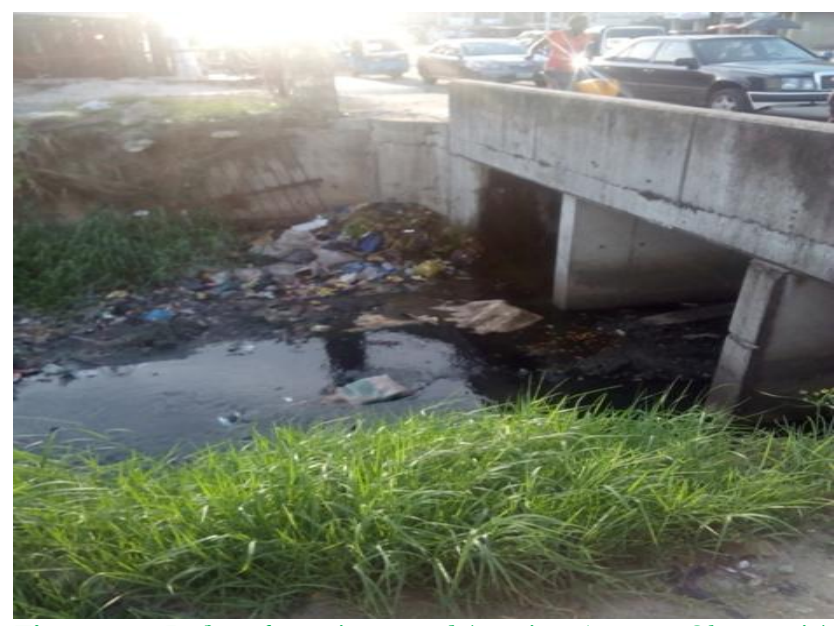

Figure-11. Refuse dump in a canal (serving Avenue-Okere axis).

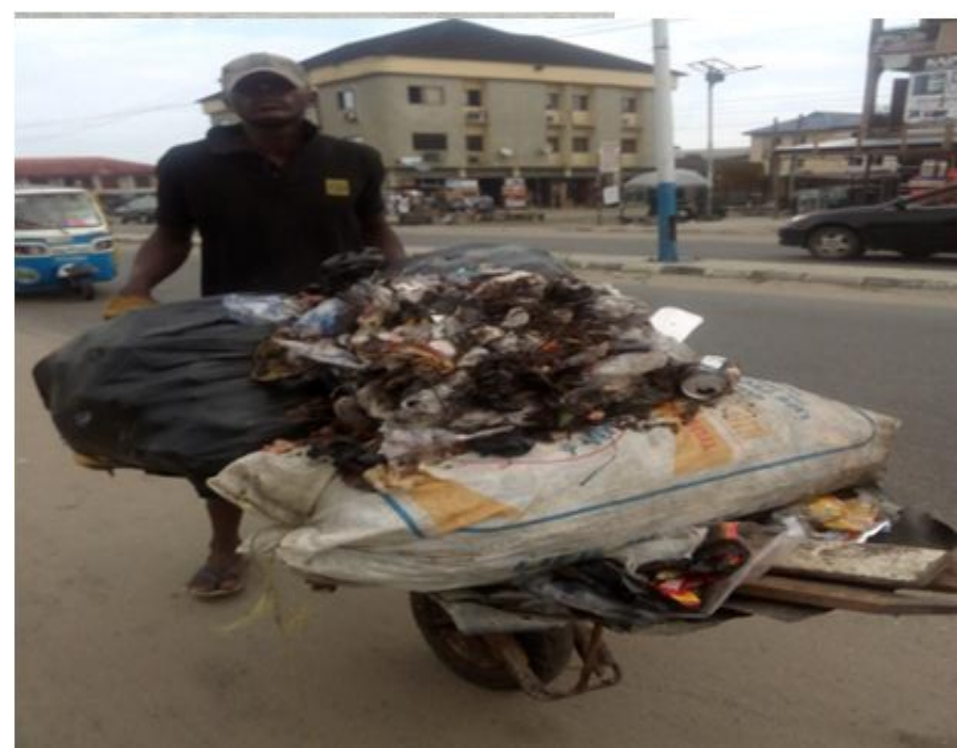

Figure-8. Informal Private Waste Collector, Okumagba Avenue Emebiren Street.

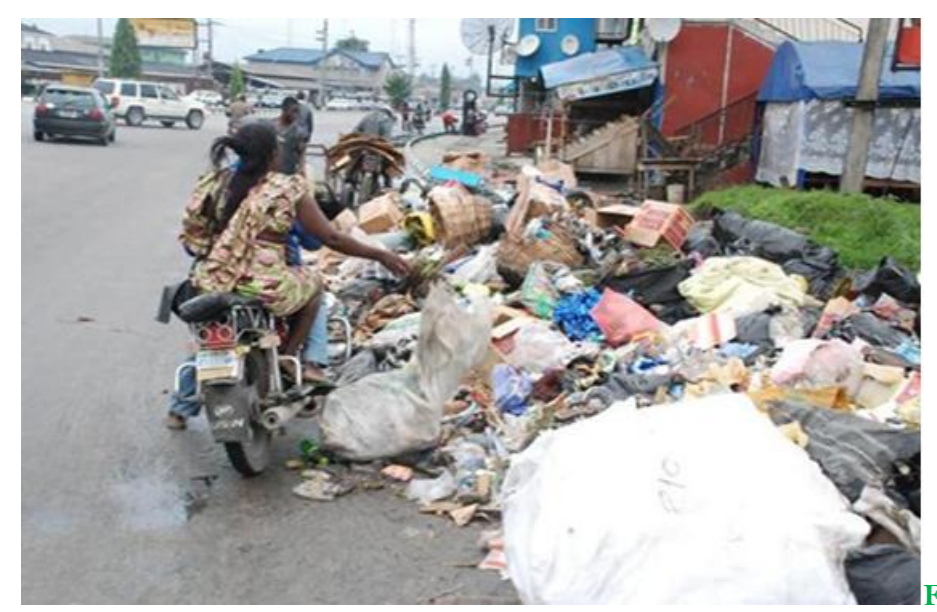

Figure-10. Indiscriminate disposal on major Road.

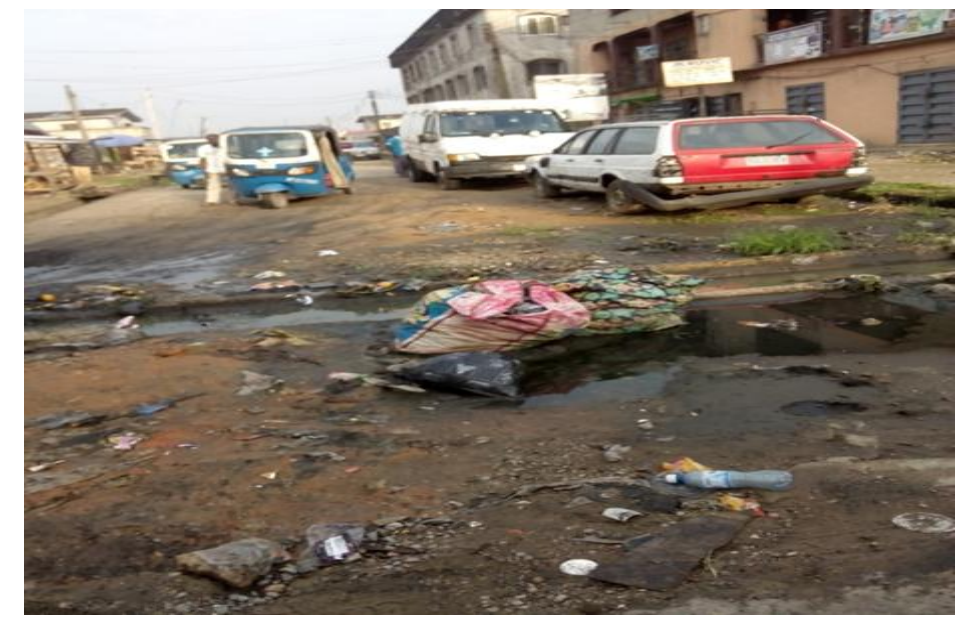

Figure-12. Refuse dump by street corner Iyesa Street Junction.

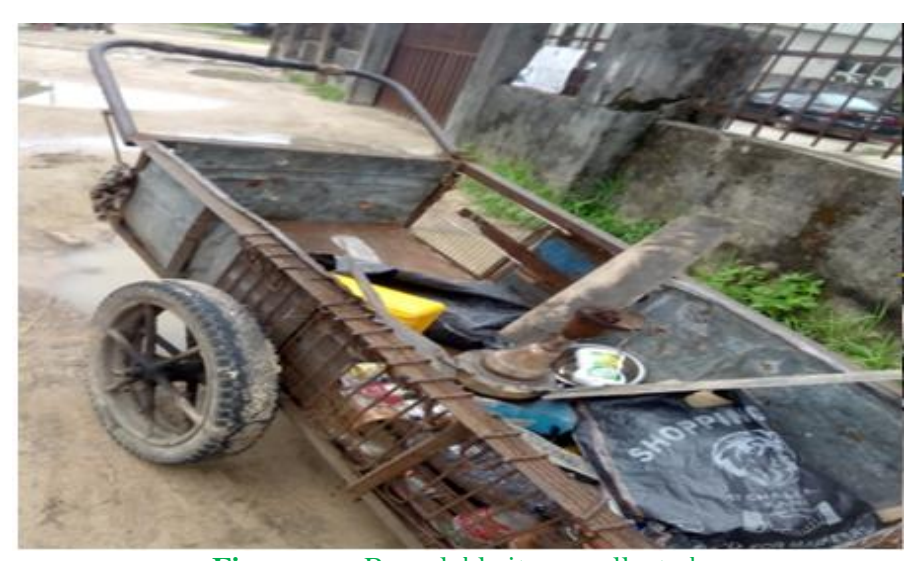

Figure-13. Recyclable items collected.

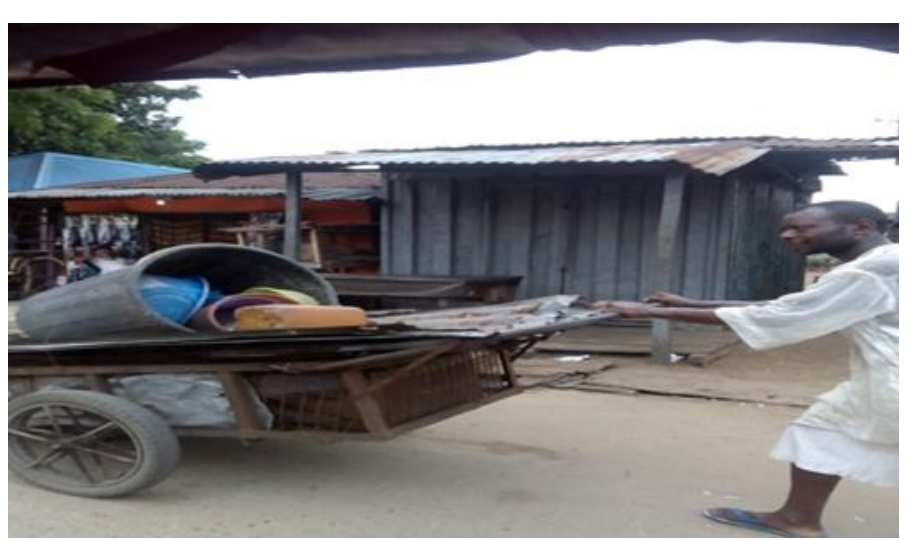

Figure-14. Scrap Buyer (Cart pusher).

Asian Online Journal Publishing Group is not responsible or answerable for any loss, damage or liability, etc. caused in relation to/arising out of the use of the content. Any queries should be directed to the corresponding author of the article. 